\title{
The Effects of Sediments Burdened by Sewerage Water Originating in Car Batteries Production in the Klenice River (CZ)
}

\author{
Petra Beránková1, Karl-Werner Schramm², Martin Bláha ${ }^{1}$, Jan Rosmus ${ }^{3}$, Pavel Čupr ${ }^{4}$ \\ ${ }^{1}$ University of South Bohemia in České Budějovice, Research Institute of Fish Culture and Hydrobiology \\ in Vodňany, Czech Republic \\ ${ }^{2}$ German Research Centre for Environmental Health, Institute of Ecological Chemistry, München, Germany \\ ${ }^{3}$ Prague State Veterinary Institute, Prague, Czech Republic \\ ${ }^{4}$ Research Centre for Environmental Chemistry and Ecotoxicology, Faculty of Science, Masaryk University, \\ Brno, Czech Republic
}

Received May 26, 2008

Accepted April 6, 2009

\begin{abstract}
The aim of this work was to perform tests of genotoxicity and toxicity on samples of riverine sediments from a location subject to motor industry load (car battery production). Together with sediment samples we also collected benthos, biofilm and juvenile fish. Concentration of lead was established in all the samples since the sewage waters discharged from the car battery production plant are heavily polluted with lead. Genotoxicity was tested with two tests of genotoxicity: the SOS chromotest and the Escherichia coli WP2 test. The toxicity of sediments was tested with a test of toxicity performed on a water crustacean Daphnia magna. A profound toxic influence upon benthic organisms was found; a consequence of the river pollution with waste water and flush water from the car battery production plant. This toxic effect was also proven by an aqueous leach from the test performed with Daphnia magna. Both tests of genotoxicity proved a significant genotoxic potential of the sediment samples linked with the growth of the concentration of lead in the sediments (up to $647 \mathrm{mg} \cdot \mathrm{kg}^{-1}$ ). The content of lead also increased in the biofilm (up to 3.37 $\mathrm{mg} \cdot \mathrm{kg}^{-1}$ of dry mass) as well as in the fish bodies (up to $804.5 \mathrm{mg} \cdot \mathrm{kg}^{-1}$ of dry mass). This thesis is the first study of the load imposed on this river as a consequence of the waste water and flush water discharge from the motor industry production plant (car battery production).
\end{abstract}

Escherichia coli, WP2, Daphnia magna, SOS chromotest, lead

Riverine sediments play an important role as pollutants and they reflect the history of river pollution (Jain 2004). Sediments act as both carriers and sinks for contaminants in aquatic environments. Trace elements, especially the so called "heavy metals", are among the most common environmental pollutants and their occurrence in waters and biota indicate the presence of natural or anthropogenic sources (Singh et al. 2005).

Aquatic sediment contaminated by heavy metals and PAHs still presents an unsolved environmental problem.

Metal concentrations in sediments can be linked to high concentrations in living organisms. The bioavailable metal load in sediments may affect the distribution and composition of benthic assemblages (Kress et al. 2004). They may be linked to high concentrations recorded in living organisms (Pempkowiak et al. 1999). The metals can be either absorbed into sediments or accumulated in benthic organism, sometimes at toxic levels (Singh et al. 2005).

The main natural source of metals in the aquatic system is the weathering of soils and rocks and anthropogenic activities, whereby industrial and urban wastes are discharged into water bodies (Pardo et al. 1990; Boughriet et al. 1992; Yu et al. 2001; Kalvins et al. 2000). Car batteries can contain up to $55 \%$ of lead. Lead along with sewage water and flush water from production plants may spread into the environment.

Most trace metals and PAHs are potentially genotoxic, which implies that they can damage DNA directly and/or generate reactive species (such as electrophilic metabolites

Address for correspondence:

Petra Beránková

Research Institute of Fish Culture and Hydrobiology

Zátiší 728/II

38925 Vodňany, Czech Republic

Phone: +420387774622

Fax: + 420383382396

E-mail: berankova@vurh.jcu.cz

http://www.vfu.cz/acta-vet/actavet.htm 
or free radicals) which can, in turn, damage DNA. Chronic exposure to such substances at an early stage of life in particular increases mutations, and consequently, dramatically increases the incidence of embryonic mortality and physiological disturbances such as teratogenesis, carcinogenesis, retardation of growth and sexual maturity, infertility, etc. (Cachot et al. 2006).

In the study by Cestari et al. (2004) a substantial negative impact of lead on the genetic material of fish cells was proven. The most common ways of damaging DNA in the tested fish have included various chromosomal abnormalities, comprising chromatid gaps and breaks, chromosomal fragmentation, chromatin decondensation and perientric inversions. Chromatid breaks were the predominant chromosomal aberrations after treatment of lead (Cestari et al. 2004). The mutagenic or clastogenic activities of lead are related to disturbances in enzyme regulation that probably affect the replication, translation and repair of the genetic material. Studies on laboratory animals have shown that exposure to lead at levels of $10 \mathrm{mg} \mathrm{Pb}^{2+} \cdot \mathrm{ml}^{-1}$ of blood leads to chromosomal aberrations (tetrapolidy, mitotic anomalies, chromatid breaks), and these effects may be related to interference with the mechanisms of replication, transcription and DNA repair (Goyer and Moore 1974).

Lead can be taken up directly from the environment by biota as well as by humans. For the last two decades the concentration of lead in the human peripheral blood has been monitored in the Czech Republic. Especially children are paid great attention to, as the toxic effect of lead endangers mostly them (Černá et al. 1997; Batáriová et al. 2006). One of the possible ways of lead penetrating into human organism is contaminated food (including fish).

The study by Altindag and Yigt (2005) revealed distinctions between the concentrations of selected heavy metals $(\mathrm{Cd}, \mathrm{Pb}, \mathrm{Hg}$, and $\mathrm{Cr})$ in different elements of aquatic ecosystems (water, plankton, sediment, and fish). With the exception of chromium the concentration of heavy metals decreases in the following order: water $>$ plankton $>$ sediment $>$ fish tissue.

Heavy metals are easily absorbed and tend to accumulate better onto soil particles than PAHs and BCPs, so the soil can be a source of all of these compounds as well as the final sink (Baveye et al. 1999; Stefanutti et al. 2002; Nicholson et al. 2003; Wang et al. 2003; Warman and Termeer 2005).

Lead is among the top 10 US EPA priority pollutants. Ferreira et al. (2004) describe the ability of lead to increase the occurrence of DNA damage. Principally it includes single strand breaks that could possibly initiate double strand breaks. This results in the inactivation or alternation of the repair mechanism. Lead bonds to mitochondrial membranes, penetrates into the mitochondrial matrix space, and is capable of uncoupling oxidative phosphorylation in brain cell mitochondria (Brierley 1977; Holtzman and Hsu 1976). Gebhart (1984) reviewed studies of chromosome damage in cells of human subjects exposed to lead and other heavy metals.

The SOS Chromotest, which measures the induction of the SOS response in Escherichia coli PQ37, has been developed by Quillardet et al. (1982) as an alternative to the Ames Test. The SOS Chromotest has been recommended for routine use in environmental applications requiring the assessment of genotoxic activity (Lan et al. 1991; Wong et al. 1994; Helma et al. 1996; Legault et al. 1996; White and Côté 1998). Several studies have also reported its usefulness in monitoring the genotoxicity of complex environmental matrices (Bombardier et al. 2001).

SOS chromotest has been employed by screening environmental studies on a long-term basis. Escherichia coli WP2 assay represents a new genotoxicity test that has not been generally employed for testing the environmental matrix yet. As follows from interlaboratory studies (Watanabe et al. 1998ab), it represents a good alternative to the Ames test which is commonly employed for testing genotoxicity of environmental samples. 
The study represents the first examination of the burdening of the sediments in the Klenice River $(\mathrm{CZ})$ and is focused on the most detailed covering of the negative effects of sewerage and flush water which contaminate the natural environment. The study combines the results of genotoxicity tests with the analysis of actual biotic samples of the stricken area.

\section{Materials and Methods}

Sampling location

The river sediment was sampled in the spring 2007 from the Klenice river (Czech Republic). The Klenice river is the left-bank tributary of the Jizera river in the Labe river basin. Its river basin occupies the area of $169.64 \mathrm{~km}^{2}$ while its length reaches $29.2 \mathrm{~km}$. The average flow in its mouth amounts to $0.44 \mathrm{~m}^{3} \cdot \mathrm{s}^{-1}$. The Klenice river joins the Jizera river near the town of Mladá Boleslav. The source of pollution is represented in the first place by car industry (namely by production of car batteries).

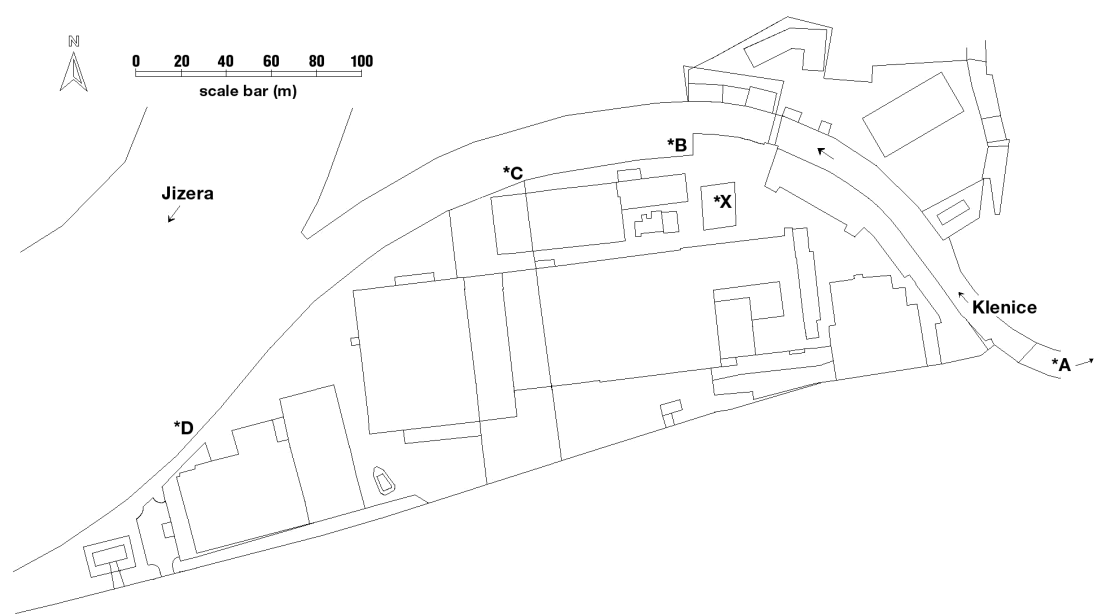

Situation plan of the sampling location on the Klenice river: *A - sample profile $\mathrm{A}, * \mathrm{~B}-$ sample profile $\mathrm{B}$, *C - sample profile C, *D - sample profile D. Sample profile A is located further upstream of the river (outside the depicted locality).

The samples were collected on four locations of the Klenice river (Scheme):

The sample profile A representing the controlling locations was gathered near the village of Řepov, 4 kilometres above its mouth into the Jizera river. This sample profile is minimally polluted by harmful substances from the town territory and lies out of the reach of pollutants related to car industry.

The sample profile B was gathered under the mouth of a small sewage clarification plant in the area where car batteries are produced. The major source of pollution in this sample profile is represented by repurified sewage water from the area containing PAHs and heavy metals.

The sample profile $\mathrm{C}$ was acquired under the mouth of rain water waste pipe from the area. The sample profile is primarily polluted by the water washed off from parking and production areas that contain PAHs and heavy metals.

The sample profile D was obtained under the junction of the Klenice River and the Jizera river. In this case, sewage water and rain water from the car industry area as well as sewage water and sink water from the area of Mladá Boleslav (all including PAHs, heavy metals and common organic pollutants) constitute the main sources of pollution.

\section{Sampling and Treatment}

The sampling was carried out in March 2007 using the Eckmann-Bridge grab sampler. Two kilograms of sediment were sampled on each of the locations. These were provided with a code and stored in a plastic bag in a cooling thermobox $\left(4^{\circ} \mathrm{C}\right)$ until laboratory processing. The samples were mechanically homogenized and dried freely at $21^{\circ} \mathrm{C}$.

For the purpose of genotoxicity tests organic extract of the samples was prepared in Soxhlet extractor in contact with dichloromethane (DCM). Ten grams of dry residue were isolated in contact with 150 millilitres of 
dichloromethane. The extract was concentrated until its amount reached approximately 5 millilitres; then it was evaporated under a nitrogen flow which was followed by its dissolution in DMSO.

For the purpose of toxicity testing by means of acute toxicity test on the water crustacean Daphnia magna (OECD 202) an aqueous leach was prepared. Fifty grams of dry residue were shaken up with 500 millilitres of standard water, conforming to the international norm ISO 9001 (i.e. deionized water) over a period of $24 \mathrm{~h}$. Then the sample was filtered through a filter with a porous diameter of $5 \mu \mathrm{m}$. The resultant filtrate was employed in the test.

Chemical analysis

The chemical analysis of samples was performed by the Prague State Veterinary Institute (CZ). Sixteen priority PAHs were determined in the sediment samples in accordance with US EPA using high-performance liquid chromatography (HPLC) with fluorescent detector following the extraction by cyclohexane in compliance with the US EPA regulation.

Lead in all of the samples was determined using mass spectrometry with inductance-coupled plasma (ICP-MS).

\section{Genotoxicity tests}

Genotoxicity of the samples was tested by means of two bacterial genotoxicity tests, with and without external metabolism activation (S9 mix), respectively. The S9 blend simulates the mammalian detoxification system. Mammalian liver enzymes can under oxidizing conditions convert some non-genotoxic materials to active genotoxic entities and vice-versa (Fish et al. 1985).

\section{SOS chromotest}

The SOS chromotest (Quillardet and Hofnung 1985; 1993) is a colorimetric assay of enzymatic activities following incubating the test strain in the presence of various amounts of sample. The strain used in this study is Escherichia coli PQ37 (provided by Prof. Quilardet, Institute Pasteur, Paris, France) that is constitutive for alkaline phosphatase synthesis. This strain exhibits $s f \mathrm{~A}:: l a c Z$ fusion and includes a deletion of the normal lac region, so that $\beta$-galactosidase activity is strictly dependent on the $s f \mathrm{~A}$ expression (Isidori et al. 2004). The assay is quantitative and dose-response curves present a linear region. The slope of the linear region allows the estimation of the SOS-inducting potency (SOSIP), which reflects the inducting activity of the sample (Hofnung and Quillardet 1986; Mersch-Sundermann et al. 1998; Quillardet and Hofnung $1985 ; 1993)$.

The SOS chromotest was performed according to a slightly modified method of Xu et al. (1989).

The SOS induction factor (IF) was then calculated for each of the test concentrations. When the induction factor in any of the test concentrations reached 1.5, the test substance was labelled as a significant genotoxin.

\section{Escherichia coli WP2 assay}

The mutagenesis assay procedure with the E. coli tryptophan-dependent bacteria is the same as those used for the Salmonella strains in the Ames test with the exception that limited tryptophan $(0.05 \mathrm{mM})$ instead of histidine is added to the top agar. This chapter provides a historical aspect of the development of the $E$. coli tryptophan reverse mutation assay in addition to guidelines for the use of the WP2 system. The different mutagenicity assay procedures described for the Salmonella assay elsewhere in this volume (Mortelmans and Zeiger 2000) are all applicable to the E. coli WP2 reverse mutation assay. The only procedural difference is the addition of limited tryptophan $(0.05 \mathrm{mM})$ instead of histidine to the top agar.

The Escherichia coli WP2 assay was performed according to a slightly modified method of Mortelmans and Riccio (2000).

The colonies were then counted and the results were expressed as the number of tryptophan revertant colonies per plate $(\mathrm{CFU})$.

Toxicity test: acute immobilization test on water flees (Daphnia magna)

Toxicity of samples was tested on the aquatic crustacean Daphnia magna. The test was performed in compliance with the methodology OECD 202 “Daphnia sp., Acute Immobilisation Test and Reproduction Test” Part I - 24 H EC50 Acute Immobilisation Test.

Biofilm (scabs) sampling

Biofilm (scabs) sampling was performed by means of scraping scabs off the top side of stones taken from the river. The samples were supplied with a code and stored in a plastic bag in a cooling thermobox $\left(4{ }^{\circ} \mathrm{C}\right)$ until their laboratory treatment. The samples were mechanically homogenized and dried freely at $21^{\circ} \mathrm{C}$.

Chemical analysis of the samples was performed by the Prague State Veterinary Institute. Lead was determined with the aid of mass spectrometry including inductance-coupled plasma (ICP-MS).

Sampling and analyzing homogenized bodies of juvenile fish

Collection of juvenile (one-year-old) cyprinids was carried out by an electrical unit. In accordance with the methodology of Randák et al. (2006) a blended sample for chemical analysis was prepared. Whole bodies of juvenile cyprinids were used for the preparation of this sample. 
Chemical analysis of the samples was performed by the Prague National Veterinary Institute. Lead was determined using mass spectrometry including inductance-coupled plasma (ICP-MS).

Sampling and treatment of macrozoobenthos (benthos)

The samples of benthos were obtained using the Eckmann-Bridge grab sampler (10 by $10 \mathrm{~cm})$ in the circumlittoral area. The specimens were separated from the substrate by a sieve and fixated in a $4 \%$ formaldehyde solution. Qualitative and quantitative sample treatment was performed by the laboratory on the next day. Using a binocular microscope, the specimens were classified as members of families and orders (where possible). Their multitude as well as their abundance $\left(\mathrm{pcs} \cdot \mathrm{m}^{-2}\right)$ and biomass $\left(\mathrm{g} \cdot \mathrm{m}^{-2}\right)$ were established.

Sampling of benthos for chemical analyses was performed accordingly. The samples were supplied with a code and stored in a plastic bag in a cooling thermobox $\left(4^{\circ} \mathrm{C}\right)$ until laboratory processing. The samples were mechanically homogenized and dried freely at $21^{\circ} \mathrm{C}$.

The Saprobic index was introduced by Pantle and Buck (1955), extended by Sládeček (1973) an adjusted by Marvan (1969). The formula for calculation is

$\mathrm{S}=\Sigma($ Si-hi-li) $/(\Sigma($ hi-li $)$

where $\mathrm{S}$ is the saprobic index of the whole community,

$\mathrm{Si}$ is the individual saprobic species index,

hi is individual species abundance,

li is the species indicative weight.

Saprobity means organic pollution, which is mainly assessed as a level of biochemically degraded substances.

Different levels of organic pollution give rise to different community of living organisms.

\section{Data evaluation}

Using ANOVA factorial the correspondence between the results of the particular tests was evaluated. Normality of the data was assessed by distribution fitting test. Differences were considered significant if $p \leq 0.05$.

\section{Results}

Chemical analysis of the sediment samples

Sixteen priority PAHs and lead were determined in the sediment samples in accordance with US EPA (Table 1).

Table 1. Results of chemical analysis of sediment samples of the Klenice River (CZ)

\begin{tabular}{|l|l|c|c|c|c|c|c|}
\hline & & $\begin{array}{c}\text { LOD } \\
\mu \mathrm{g} \cdot \mathrm{kg}^{-1}\end{array}$ & RSD \% & Sample A & Sample B & Sample C & Sample D \\
\hline Lead & $\mathrm{mg} \cdot \mathrm{kg}^{-1}$ & $\begin{array}{c}\mathrm{mg} \cdot \mathrm{kg}^{-1} \\
0.05\end{array}$ & 8 & 7.42 & 307.00 & 647 & 126 \\
\hline Benzo(a)anthracene & $\mu \mathrm{g} \cdot \mathrm{kg}^{-1}$ & 0.05 & 10 & $<0.05$ & $<0.05$ & $<0.05$ & $<0.05$ \\
\hline Benzo(a)pyrene & $\mu \mathrm{g} \cdot \mathrm{kg}^{-1}$ & 0.05 & 6 & $<0.05$ & $<0.05$ & $<0.05$ & $<0.05$ \\
\hline Benzo(b)fluoranthene & $\mu \mathrm{g} \cdot \mathrm{kg}^{-1}$ & 0.10 & 7 & $<0.10$ & $<0.10$ & $<0.10$ & $<0.10$ \\
\hline Benzo(k)fluoranthene & $\mu \mathrm{g} \cdot \mathrm{kg}^{-1}$ & 0.02 & 6 & $<0.02$ & $<0.02$ & $<0.02$ & $<0.02$ \\
\hline Indenol(1,2,3-cd)pyrene & $\mu \mathrm{g} \cdot \mathrm{kg}^{-1}$ & 0.30 & 11 & $<0.30$ & $<0.30$ & $<0.30$ & $<0.30$ \\
\hline Dibenzo(a,h)anthracene & $\mu \mathrm{g} \cdot \mathrm{kg}^{-1}$ & 0.10 & 5 & $<0.10$ & $<0.10$ & $<0.10$ & $<0.10$ \\
\hline Benzo(g,h,i)perylene & $\mu \mathrm{g} \cdot \mathrm{kg}^{-1}$ & 0.10 & 7 & $<0.10$ & $<0.10$ & $<0.10$ & $<0.10$ \\
\hline Chrysene & $\mu \mathrm{g} \cdot \mathrm{kg}^{-1}$ & 0.05 & 5 & $<0.05$ & $<0.05$ & $<0.05$ & $<0.05$ \\
\hline Naphthalene & $\mu \mathrm{g} \cdot \mathrm{kg}^{-1}$ & 0.25 & 14 & 0.83 & 11.25 & 10.61 & 12.94 \\
\hline Acenaphtene & $\mu \mathrm{g} \cdot \mathrm{kg}^{-1}$ & 0.20 & 12 & 0.11 & 0.57 & 0.29 & 0.32 \\
\hline Fluorene & $\mu \mathrm{g} \cdot \mathrm{kg}^{-1}$ & 0.10 & 12 & 0.20 & 1.12 & 0.45 & 0.39 \\
\hline Phenanthrene & $\mu \mathrm{g} \cdot \mathrm{kg}^{-1}$ & 0.05 & 9 & 0.72 & 1.95 & 0.64 & 0.69 \\
\hline Anthracene & $\mu \mathrm{g} \cdot \mathrm{kg}^{-1}$ & 0.01 & 11 & 0.03 & 0.31 & 0.11 & 0.11 \\
\hline Fluoranthene & $\mu \mathrm{g} \cdot \mathrm{kg}^{-1}$ & 0.40 & 8 & 0.08 & 0.31 & 0.13 & 0.17 \\
\hline Pyrene & $\mu \mathrm{g} \cdot \mathrm{kg}^{-1}$ & 0.20 & 5 & 0.05 & 0.19 & 0.08 & 0.09 \\
\hline$\Sigma$ PAHs & $\mu \mathrm{g} \cdot \mathrm{kg}^{-1}$ & & & 2.02 & 15.7 & 12.31 & 14.71 \\
\hline Dry mass & $\mathrm{g} \cdot 100 \mathrm{~g}^{-1}$ & & & 99.19 & 96.33 & 95.08 & 98.00 \\
\hline
\end{tabular}

LOD - detection limit $\left[\mathrm{mg} \cdot \mathrm{kg}^{-1}\right]$ for lead and $\left[\mu \mathrm{g} \cdot \mathrm{kg}^{-1}\right]$ for PAHs

RSD - repeatability of the metod [\%] 
The highest concentration of PAHs was detected in the second sample profile, located under the mouth of a small sewage clarification plant in the area where car batteries are produced. In the third sample profile located under the mouth of rain water waste pipe from the area the highest concentration of lead $\left(647 \pm 8 \mathrm{mg} \cdot \mathrm{kg}^{-1}\right)$ was measured. A marked decline in the concentration of the monitored substances was noted in the third sample profile located under the junction of the Klenice and the Jizera rivers. At this point the Klenice water gets diluted by the Jizera water.

Genotoxocity Tests

SOS Chromotest

In the SOS chromotest the concentrations of $0.15,0.075$ a $0.0375 \mathrm{~g} \cdot \mathrm{ml}^{-1}$ were tested.

The results of the SOS chromotest for the version excluding S9 fraction (Fig. 1a) show significant differences between the tested samples $(\mathrm{F}=17.098 ; \mathrm{DF}=3 ; p<0.05)$ as well as the tested concentrations $(\mathrm{F}=8.315 ; \mathrm{DF}=2 ; p<0.05)$. In all concentrations of various samples the value of the inductive factor (IF) reflects the same tendency $(\mathrm{F}=2.088 ; \mathrm{DF}=6 ; p=0.925)$. All of the tested samples demonstrated a genotoxic effect (IF $>1.5)$ in all of the tested concentrations (Fig. 2a). Only sample D at the lowest concentration did not reach the limit.
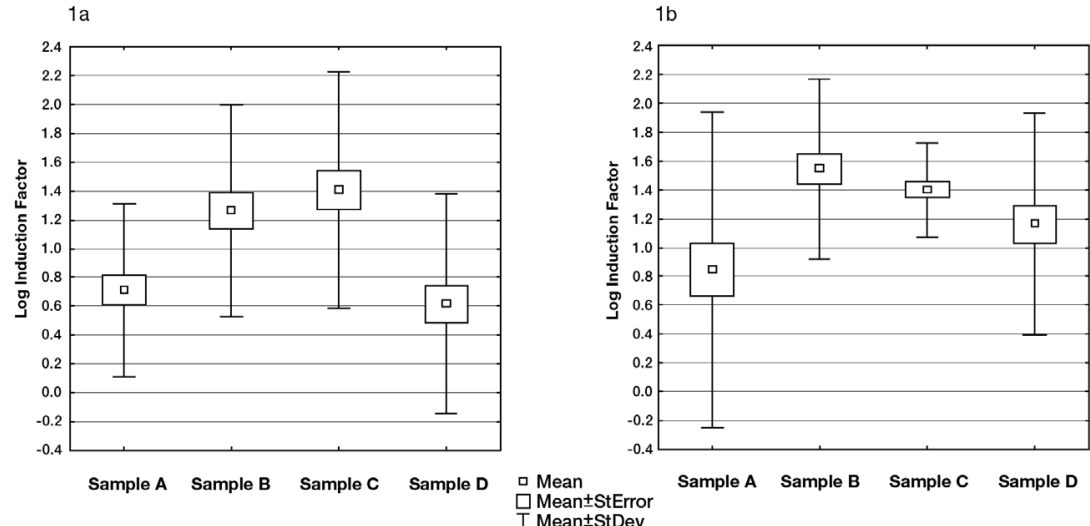

Fig. 1. Results of SOS chromotest of organic extract of sediment samples acquired from the Klenice River (CZ). Variability is expressed by Standard Deviation (SD). Fig. 1a represents the version without the addition of S9 fraction, Fig. $1 \mathrm{~b}$ represents the version with the addition of $\mathrm{S} 9$ fraction.

The results of the SOS chromotest for the version including S9 fraction (Fig. 1b) show significant differences between the tested samples $(\mathrm{F}=38.482 ; \mathrm{DF}=3 ; p<0.05)$ as well as the tested concentrations $(\mathrm{F}=70.625 ; \mathrm{DF}=2 ; p<0.05)$. A consonant tendency for all concentrations of various samples was not determined $(\mathrm{F}=7.382 ; \mathrm{DF}=2 ; p<0.05)$. All of the tested samples demonstrated a genotoxic effect (IF $>1.5$ ) in all of the tested concentrations (Fig. 2b). Only sample A at the lowest concentration did not reach the limit.

Escherichia coli WP2 sssay

In Escherichia coli WP2 assay the concentrations of $0.2 ; 0.1 ; 0.05$ and $0.025 \mathrm{~g} \cdot \mathrm{ml}^{-1}$ were tested.

The results of Escherichia coli WP2 assay for the version excluding S9 fraction (Fig. 3a) show significant differences between the tested samples $(\mathrm{F}=35.16$; $\mathrm{DF}=3$; 

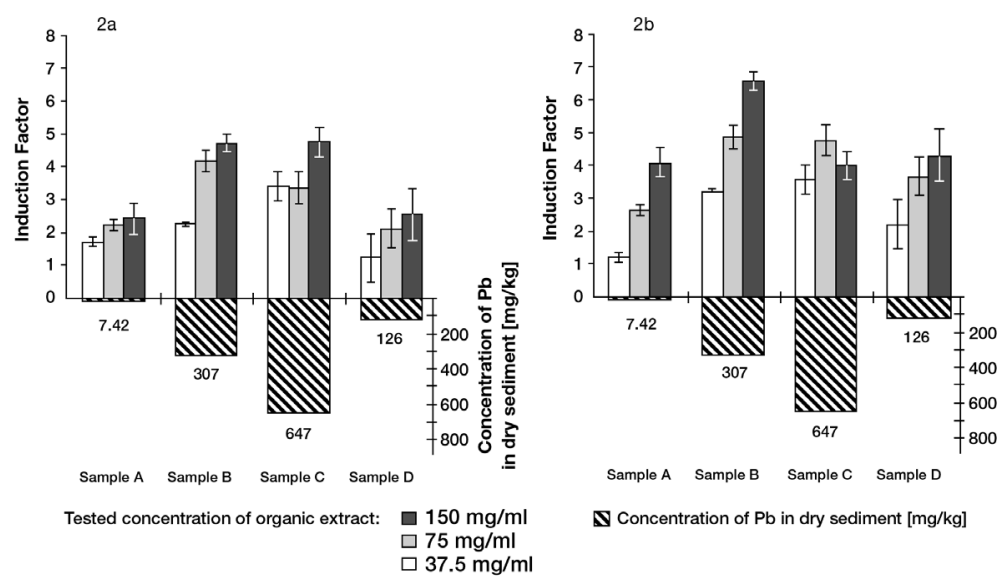

$\mathbf{N}$ Concentration of $\mathrm{Pb}$ in dry sediment $[\mathrm{mg} / \mathrm{kg}]$

Fig. 2. Results of SOS chromotest of tested concentration of organic extract of sediment samples acquired from the Klenice River (CZ) and concentration of lead in dry sediment. Fig. 2a represents the version without the addition of $\mathrm{S} 9$ fraction, Fig. $2 \mathrm{~b}$ represents the version with the addition of $\mathrm{S} 9$ fraction.

$p<0.05)$ as well as the tested concentrations $(\mathrm{F}=4.86 ; \mathrm{DF}=3 ; p<0.05)$. In all of the concentrations of all samples the number of CFU reflected the same tendency $(\mathrm{F}=$ $0.59 ; \mathrm{DF}=9 ; p 0.79)$. All of the tested samples demonstrated a genotoxic effect (CFU $>$ number of CFU in the negative control, CFU of the negative control $=24$ ) at all of the tested concentrations (Fig. 3b). Only sample A at the lowest concentration did not reach the limit.

The results of Escherichia coli WP2 assay for the version including S9 fraction (Fig. 3b) show significant differences between the tested samples $(\mathrm{F}=82.58 ; \mathrm{DF}=3 ; p<0.05)$ as well as the tested concentrations $(\mathrm{F}=10.01 ; \mathrm{DF}=3 ; p<0.05)$. In all of the concentrations of all samples the number of CFU reflected the same tendency $(\mathrm{F}=0.95 ; \mathrm{DF}=9$; $p=0.498)$. All of the tested samples demonstrated a genotoxic effect (CFU $>$ number of CFU in the negative control, $\mathrm{CFU}$ of the negative control $=24$ ) at all of the tested concentrations (Fig. 4b). Only sample A at the lowest concentration did not reach the limit.

Toxicity test: acute immobilization test on water flees (Daphnia magna)

In acute immobilization test on water flees the sample concentration of $1 \mathrm{~g} \cdot \mathrm{ml}^{-1}$ was tested. Sample A did not produce any toxic effects ( $0 \%$ mortality). Sample B demonstrated strong toxic effects (100\% mortality). Sample C showed toxic effects (30\% mortality). Sample D produced moderate toxic effects (10\% mortality).

\section{Biofilm}

In biofilm samples the content of lead was determined (Table 2). The highest lead concentration was detected in the sample acquired from profile $\mathrm{C}\left(804.5 \mathrm{mg} \cdot \mathrm{kg}^{-1}\right.$ dry weight $)$ and the lowest concentration was detected from profile $\mathrm{A}\left(9.50 \mathrm{mg} \cdot \mathrm{kg}^{-1} \mathrm{dry}\right.$ weight $)$. A marked decline in lead concentration followed the junction with the Jizera river (131.0 $\mathrm{mg} \cdot \mathrm{kg}^{-1}$ dry weight).

Table 2. Results of assessment of lead concentration $\left(\mathrm{mg} \cdot \mathrm{kg}^{-1}\right.$ of dry mass) in biofilm and juvenile fish acquired from the Klenice River $(\mathrm{CZ})$

\begin{tabular}{|l|c|c|c|c|}
\hline Matrix & Sample A & Sample B & Sample C & Sample D \\
\hline Biofilm & 9.50 & 383.1 & 804.5 & 131.0 \\
\hline Juvenile fish & 0.89 & 3.38 & 3.37 & 1.74 \\
\hline
\end{tabular}


$3 a$

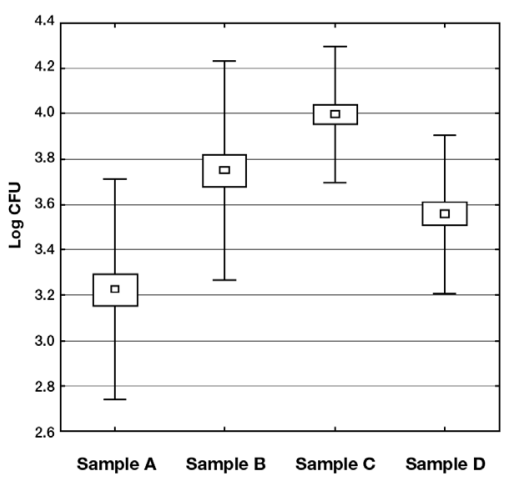

$3 b$

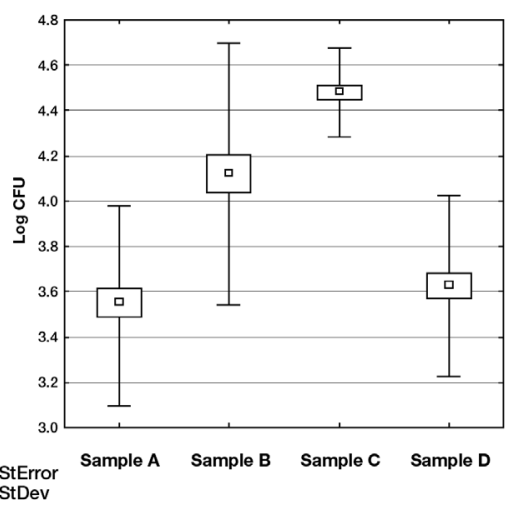

Fig. 3. Results of Escherichia coli WP2 assay of organic extract of sediment samples acquired from the Klenice River (CZ). Variability is expressed by Standard Deviation (SD). Fig. 3a represents the version without the addition of S9 fraction, Fig. 3b represents the version with the addition of S9 fraction.

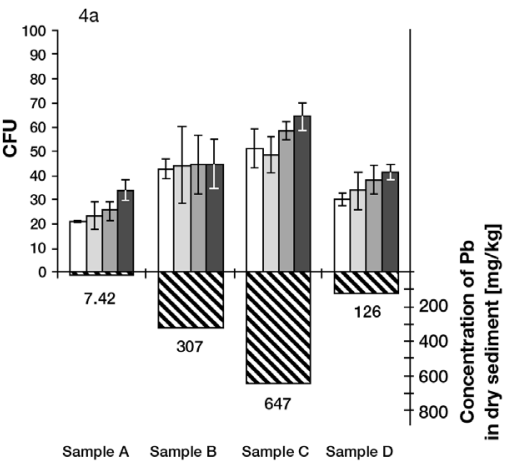

Tested concentration of organic extract:

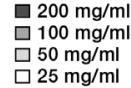

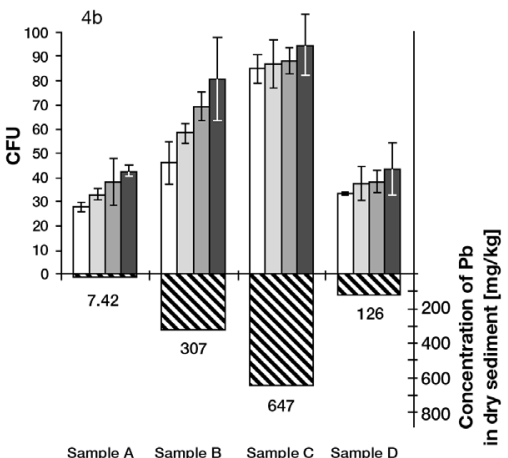

Sample A Sample B Sample C Sample D

$\mathbf{N}$ Concentration of $\mathrm{Pb}$ in dry sediment $[\mathrm{mg} / \mathrm{kg}]$

Fig. 4. Results of Escherichia coli WP2 assay of tested concentration of organic extract of sediment samples acquired from the Klenice River (CZ) and concentration of lead in dry sediment. Fig. 4a represents the version without the addition of S9 fraction, Fig. $4 \mathrm{~b}$ represents the version with the addition of S9 fraction.

\section{Juvenile fish}

In the samples of juvenile fish the content of lead was determined. As with the biofilm, the highest concentration was detected in the sample from profile $\mathrm{C}\left(3.37 \mathrm{mg} \cdot \mathrm{kg}^{-1}\right.$ dry weight $)$ and the lowest concentration was detected from profile $\mathrm{A}\left(0.89 \mathrm{mg} \cdot \mathrm{kg}^{-1}\right.$ dry weight $)$. A marked decline in lead concentration again followed the junction with the Jizera river (1.74 mg $\cdot \mathrm{kg}^{-1}$ dry weight).

\section{Benthos}

Eight kinds of benthic organisms ranked into 4 groups (Table 3) were found present in the sample from the inspection area (sample profile A). The total saprobic index $(\mathrm{S}=3)$ corresponds to a biotop with an increased amount of organic substances coming from anthropogenic activity (alphamesosaprobity). The indicator character for 


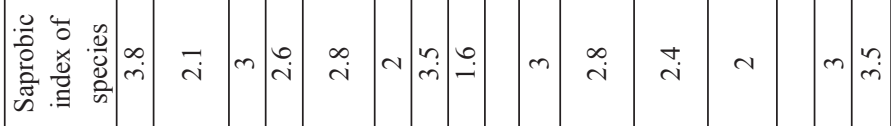

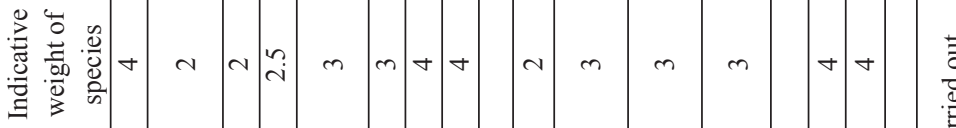

U

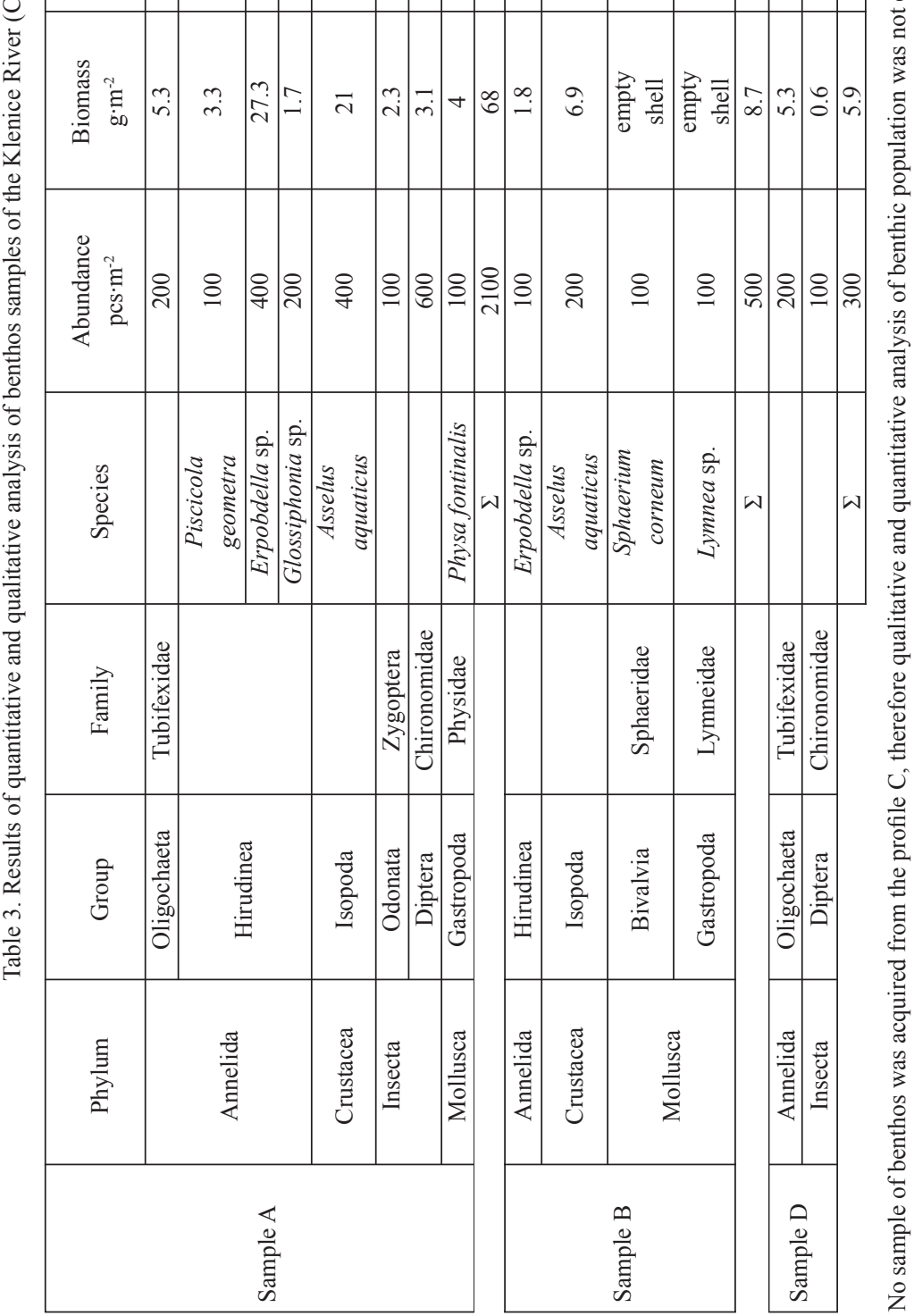


alphamesosaprobity was detected in the water louse (Asellus aquaticus) only, the remaining species can be distinguished by greater quantivalence.

No benthic organisms were located in sample profile B. In order to assess the effect of the drains emptied into the profile in question more accurately, the occurrence of benthos was investigated also directly above the drain. Three groups of organisms and four species were discovered (Table 3). Saprobic index $(S=2.6)$ corresponds to bottom bound of alphamesosaprobity on the verge with betamesosaprobity.

No benthic organisms were located in sample profile C.

Two groups of organisms were located in sample profile D (Table 3). Saprobic index ( $\mathrm{S}=$ 3.2) corresponds to alphamesosaprobity. The presence of heddle (Tubifex tubifex) indicates rather polysaprobity of which strong pollution by organic substances is typical.

\section{Discussion}

The results of chemical analyses and genotoxicity tests confirmed the same tendency of the pollution development progressing in the direction from the spring towards the river mouth. This direction was established by the general rules of the increase of concentration of pollutants due to the flow of waste waters. The least genotoxic effect was displayed by a sample from the control location $4 \mathrm{~km}$ up the river from the first production plant discharge outlet (MIF for the SOS chromotest without fraction S9 2.4 with fraction S9 4.1). The sample collected under the confluence of the Klenice river and Jizera river (MIF for the SOS chromotest without fraction S9 2.5 with fraction S9 4.3) where the waters mixed and diluted, also displayed low genotoxicity.

The increase of MIF after the addition of the S9 fraction is determined by the increase of genotoxic effects of PAHs contained in the sample after their metabolic activation. In sampling profile B (under the discharge outlet of a small wastewater treatment plant belonging to the production area) there was, in accord with the chemical analysis, an increase of the genotoxic effect (MIF for the SOS chromotest without fraction S9 4.7 with fraction $\mathrm{S} 9$ 6.6). Under the inflow of the wastewater from the car battery production area (profile C) there was an increase of the genotoxic potential on MIF for the SOS chromotest without fraction S9 4.8 with fraction S9 4.8. In this sample there was no increase of the genotoxic effect due to the metabolic processes simulated by the addition of the rat liver homogenizer.

There was a lower concentration of detected PAHs in sample C compared with sample B. PAHs could be activated by mammalian enzymes therefore no difference in the reactions between the versions with and without the addition of the S9 fraction.

The increase of genotoxic reaction after the addition of the S9 fraction is in accordance with other studies in which sediments were tested with the SOS chromotest (White et al. 1998; Langevin et al. 1992; Lan et al. 1991; Buchman 1990).

Both the SOS chromotest and the Escherichia coli WPS test displayed the lowest genotoxic potential in sample A (the controlling locations) and sample D (the junction of the Klenice and Jizera rivers); the tests gave these results both in the version with and in the version without the S9 fraction.

After adding the S9 fraction to samples B, there was a significant increase of the genotoxic potential (under the inflow from the wastewater treatment plant of the car battery production area) and to samples $\mathrm{C}$ (the influx of waste waters from the car battery production area). In the literature available at present, there are no studies published which performed tests of natural sediments in the same testing system.

The published studies imply that the reaction of the Escherichia coli WPS test is in a good accord with the classic Ames test TA102 a TA2638 (Wilcox 1990; Watanabe et al. 1998a; 1998b). Sediments of the Po river were tested negative on TA98, TA100 and TA102 
with or without S9 (Vigano et al. 2002). However, for sediment testing the Ames test uses more frequently TA98, TA100 and TA97 strains (White et al. 2004).

We assume on the basis of our observations and monitoring that an essential part of the genotoxic effect in the sediment samples from the Klenice river is played by the increased content of lead. We have two reasons for this assumption:

1. Concentration of 16 detected PAHs ( $\Sigma$ 16 US EPA PAHs $2.2-14.71 \mu \mathrm{g} \cdot \mathrm{kg}^{-1}$, Table 1 ) in the sediment samples is lower than in the industry-loaded locations (Svobodová et al. 2004). The concentration of PAHs placed according to the IARC into groups $2 \mathrm{~A}$ and 2B [benzo(a)anthracene, benzo(a)pyrene, benzo(b)fluoranthene, benzo(k) fluoranthene, indenol $(1,2,3,-\mathrm{c}, \mathrm{d})$ pyrene a dibenzo(a,h)antracene] is found even under the detection limit (Table 1). Concentration of PAHs in sediments that is so low is clearly due to the absence of industrial plants and large human residences in the basin area of the Klenice river. In their work, Frouin et al. (2007) report a concentration of $129 \mathrm{ng} \cdot \mathrm{g}^{-1}$ in the control sediment and a concentration of $22,550 \mathrm{ng} \cdot \mathrm{g}^{-1}$ in smelter soot sediment. In sediments from different parts of the USA, concentrations of PAHs were determined in the range of 644 to $55,612 \mathrm{ng} \cdot \mathrm{g}^{-1}$ (Jarvis et al. 1996). In the mouth of the Yangtze River (China), Liu et al. (2000) measured a concentration of PAHs from 0.08 to $11.4 \mu \mathrm{g} \cdot \mathrm{g}^{-1}$.

2. In the work of Cestari et al. (2004) a significant negative influence of lead upon the genetic material of fish cells was proven. The most frequent ways of damage to the DNA of the test fish were various chromosomal abnormalities, including chromatid gaps and breaks, chromosomal fragmentation, chromatin decondensation and perientric inversions. Chromatid breaks were the predominant chromosomal aberrations after treatment of lead (Cestari et al. 2004). The mutagenic or clastogenic activities of lead are related to disturbances in enzyme regulation that probably affect the replication, translation and repair of genetic material (Goyer and Moore 1974). Studies in laboratory animals have shown that exposure to lead at levels of $10 \mathrm{mg} \mathrm{Pb}{ }^{2+} \cdot \mathrm{ml}^{-1}$ of blood leads to chromosomal aberrations (tetrapolidy, mitotic anomalies, chromatid breaks), and these effects may be related to interference with the mechanisms of replication, transcription and DNA repair (Goyer and Moore 1974).

The content of lead detected in the samples of sediments collected from the Klenice river $\left(7.42-647 \mathrm{mg} \cdot \mathrm{kg}^{-1}\right.$ ) (Table 1) is in comparison with the available data higher than in other rivers in the Czech Republic, e.g. the Tichá Orlice river reaches a range of lead content of 31.3 to $36.6 \mathrm{mg} \cdot \mathrm{kg}^{-1}$ (Svobodová et al. 2004). The increase of the content of lead under the discharge outlets of the car battery production plant in comparison to the control location located $4 \mathrm{~km}$ up the river from the first production plant discharge outlet $\left(7.42 \mathrm{mg} \cdot \mathrm{kg}^{-1}\right)$ is due to the nature of waste water pollution in this location. These waters are being highly polluted with lead during the production process, because car batteries contain up to $55 \%$ of lead. A similar situation is also in other parts of the world. For example, Singh et al. (2005) measured in the sediments of the river Ganges (India) a content of lead in the range of 6.27 to $68.73 \mu \mathrm{g} \cdot \mathrm{kg}^{-1}$, in the Po river (Italy) a range of 32 to $98.5 \mathrm{mg} \cdot \mathrm{kg}^{-1}$ (Farkas et al. 2007) and Cachot et al. (2006) measured in the Seine river (France) $2-76.6 \mathrm{mg} \cdot \mathrm{kg}^{-1}$. Johns on (1998) found lead in suspended sediment to range around $40 \mu \mathrm{g} \cdot \mathrm{kg}^{-1}$ in rural streams and rivers but reached 150 to $350 \mu \mathrm{g} \cdot \mathrm{kg}^{-1}$ in urban industrial areas.

Altindag and Yigt (2005) describe differences in concentrations of selected heavy metals (including $\mathrm{Pb}$ ) in various elements of water ecosystems. According to the authors the concentration of these heavy metals decreases as follows: water $>$ plankton $>$ sediment $>$ fish tissue. This sequence is maintained even with the samples from the Klenice river: biofilm $\left(5.5-804.5 \mathrm{mg} \cdot \mathrm{kg}^{-1}\right.$ of dry mass $)>$ sediment $\left(0.05-647 \mathrm{mg} \cdot \mathrm{kg}^{-1}\right)>$ alevin $(0.89-$ $3.38 \mathrm{mg} \cdot \mathrm{kg}^{-1}$ of dry mass). 
In the tissues of Abramis brama L. of the west bank of the Lake Balaton (Hungary) the lead concentration ranging from 44 to $3.24 \mathrm{mg} \cdot \mathrm{kg}^{-1}$ of dry mass was determined by Franks et al. (2007). In the study by Begum et al. (2005) the average lead concentration of $2.08 \mathrm{mg} \cdot \mathrm{kg}^{-1}$ of dry mass was found in the tissues of the fish Tilapia nilotica, Cirrhina mrigala and Clarirus batrachus of Dhanmondi Lake in Bangladesh. The maximal limit of lead accepted in fish meat by European Union (EU) is 0.96 $\mathrm{mg} \cdot \mathrm{kg}^{-1}$ of dry mass.

The screening benchmark has been selected utilizing numerous criteria. Priority has been given to values based on direct toxicity over food chain modelling, as site-specific food chain exposure modelling (MacDonald et al. 2000). The values of environmental screening risk (ESR) calculated for observed sampling localities have exceeded critical value 1 (location $\mathrm{B} E S R=8.58$, location $\mathrm{C} \mathrm{ESR}=18.07$, and location $\mathrm{D} E S R=3,52$ ). In case of exceeding ESR $=1$ the usage of biological tests for the confirmation of negative biological effects is recommended. The ESR value for sample A (rear location) has also reached 0.21 .

There is no presence of macrozoobenthos under sewerage water outfall which could be related to high concentration of lead or other undetected substances and their negative influence on condition of benthic organisms (Robson 2006; Fargasova 1994). Mebane et al. (2008) performed toxicity test of lead on mortality and fertility level in chironomid larvae and reported negative effects even at lower lead concentrations than in the Klenice river. Namely, chironomid larvae are able to build up some tolerance on heavy metal concentration in water, as are copper or zinc, but in the case of cadmium and lead this ability is minimal.

The results of the performed monitoring indicate that the ecosystem of the Klenice river is heavily damaged in consequence of pollution with waste waters containing high concentrations of lead. Lead is being stored in the bottom sediments. From there, it can be released through the activity of benthic organisms or from the sedimental swirling caused by an increased flow. In both cases, the probability of lead entering the food chain increases.

The production of lead car batteries in the observed location has been terminated. Further contamination of the Klenice river can therefore only take place by flush water from the former production area.

With regard to the possibility of fish migration, it could be appropriate to fish out the Jizera river above and under the mouth of the Klenice river and determine concentration of lead in fish samples.

\section{Účinky sedimentů zatížených odpadními vodami z výroby autobaterií, řka Klenice (ČR)}

Cílem této práce bylo provedení testů genotoxicity a toxicity vzorků říčních sedimentů z lokality zatížené automobilovým průmyslem (výroba autobaterií). Zároveň s odběrem sedimentů byl proveden i odběr bentosu, biofilmu a juvenilních ryb. Ve všech vzorcích byla stanovena koncentrace olova nebot' odpadní vody z výroby baterií jsou silně znečištěny olovem. Genotoxicita byla testována dvěma testy genotoxicity: SOS chromotestem a Escherichia coli WP2 testem. Toxicita sedimentů byla testována testem toxicity na vodním korýši Daphnia magna. Byl zjištěn silný toxický účinek na bentické v důsledku znečištění toku odpadními a splachovými vodami z areálu výroby autobaterií. Silný toxický účinek vykázal i vodný výluh sedimentů v testu s Daphnia magna. Oba testy genotoxicity prokázaly významný genotoxický potenciál vzorků sedimentů v návaznosti na nárůst koncentrace olova v sedimentech (až $647 \mathrm{mg} \cdot \mathrm{kg}^{-1}$ ). Zvýšený byl i obsah olova v biofilmu (až $3.37 \mathrm{mg} \cdot \mathrm{kg}^{-1}$ sušiny) a těle ryb (až $804.5 \mathrm{mg} \cdot \mathrm{kg}^{-1}$ sušiny). Tato práce je první studií 
zatížení tohoto toku v důsledku vypouštění odpadních a splachových vod z areálu automobilového průmyslu (výroba autobaterií).

\section{Acknowledgements}

This study was supported by the project MSM 6007665809 (Ministry of Education, Youth and Sports of the Czech Republic) and the project SP/2e7/229/07 (Ministry of Environment of the Czech Republic) and cooperation of Research Centre for Environmental Chemistry and Ecotoxicology, Faculty of Science, Masaryk University, Brno, Czech Republic and German Research Centre for Environmental Health, Institute of Ecological Chemistry, München, Germany

\section{References}

Altindag A, Yigit S 2005: Assessment of heavy metal concentrations in the food web of lake Beysehir, Turkey. Chemosphere 60: $552-556$

Begum A, Amin MN, Kaneco S, Ohta K 2005: Selected elemental composition of the muscle tissue of three species of fish, Tilapia nilotica, Cirrhina mrigala and Clarius batrachus, from the fresh water Dhanmondi Lake in Bangladesh. Food Chem 93: 439-443

Buchman MF 1990: A new microbial bioassay for screening of sediment mutagenicity. Can Tech Rep Fish Aquat Sci 1774: 978-990

Cachot J, Geffard O, Augagneur S, Lacroix S, Le Menach K, Peluhet L, Couteau J, Denier X, Devier MH, Potiier D, Budzinski H 2006: Evidence of genotoxicity related to high PAH content of sediments in the upper part of the Seine estuary (Normandy, France). Aquat Toxicol 79: 257-267

Cestari MM, Lemos PMM, Ribeiro CAD, Costa JMRA, Pelletier E, Ferraro MVM, Mantovani MS, Fenocchio AS 2004: Genetic damage induced by trophic doses of lead in the neotropical fish Hoplias malabaricus (Characiformes, Erythrinidae) as revealed by the comet assay and chromosomal aberrations. Genet Mol Biol 27: 270-274

Fargasova A 1994: A comparative-study of the toxicity and inhibitora effects of inorganic tin-compounds on various biological subjects. Biologia 49: 307-311

Farkas A, Erratico C, Vigano L 2007: Assessment of the environmental significance of heavy metal pollution in surficial sediments of the River Po. Chemosphere 68: 761-768

Fish F, Lampert I, Halachmi A, Riesenfeld G, Herzberg M 1985: The SOS chromotest kit-a rapid method for the detection of genotoxicity. In Reports of the $2^{\text {nd }}$ International Symposium on Toxicity Testing using Bacteria, Banff, Canada, pp. 1-24

Frouin H, Pellerin J, Fournier M, Pelletier E, Richard P, Pichaud N, Rouleau C, Garnerot F 2007: Physiological effects of polycyclic aromatic hydrocarbons on soft-shell clam Mya arenaria. Aquat Toxicol 82: 120-134

Hofnung M, Quillardet P 1986: Recent developments in bacterial short-term tests for the detection of genotoxic agents. Mutagenesis 1: 319-330

Isidori M, Lavorgna M, Nardelli A, Parrella A 2004: Integrated environmental assessment of Volturno River in South Italy. Sci Total Environ 327: 123-134

Johnson FM 1998: The genetic effects of environmental lead. Mutat Res 410: 123-140

Lan Q, Dickman M, Alvarez M 1991: Evidence of genotoxic substances in the Niagara River watershed. Environ Toxicol Water Quality 6: 1-15

Langevin R, Rasmussen JB, Sloterdijk H, Blaise C 1992: Genotoxicity in water and sediment extracts from StLawrence River system, using the SOS Chromotest. Water Res 26: 419-429

Liu M, Baugh PJ, Hutchinson SM, Yu L, Xu S 2000: Historical record and sources of polycyclic aromatic hydrocarbons in core sediments from the Yangtze Estuary, China. Environ Pollut 110: 357-365

MacDonald DD, Ingersoll CG, Berger TA 2000: Development and evaluation of consensus-based sediment quality guidelines for freshwater ecosystems. Arch Environ Contam Toxicol 39: 20-31

Marvan P 1969: Primetchanija k primeneniju statistitcheskich metodov po opredeleniju saprobnosti. Simposium SEV. Voprosy saprobnosti, Zivogost. p.19-43 (in Russian)

Mebane CA, Hennessy DP, Dillon FS 2008: Developing acute-to-chronic toxicity rations for lead, cadmium, and zinc using rainbow trout, a mayfly, and midge. Water Air Soil Pollut 188: 41-66

Mersch-Sundermann V, Kevekordes S, Jenter C 1998: Testing of SOS induction of artificial polycyclic musk fragments in E. coli PQ37 (SOS chromotest). Toxicol Lett 95: 147-154

Mortelmans K, Ricco ES 2000: The bacterial tryptophan reverse mutation assay with Escherichia coli WP2. Mutat Res 455: 61-69

Mortelmans K, Zeiger E 2000: The Ames Salmonella/microsome mutagenicity assay, Mutat Res 455: 29-60

OECD 2002 "Daphnia sp. Acute Imobilisation Test and Reproduction test" Part I - 24 H EC50 Acute Immobilisation Test 1996

Pantle R, Buck H 1955: Die biologische Überwachung der Gewässer und die Darstellung der Ergebnisse. Gas und Wasserfach 96: 603 (in German)

Quillardet P, Hofnung M 1985: The SOS chromotest, a colorimetric bacterial assay for genotoxins - procedures. Mutat Res 147: 65-78

Quillardet P, Hofnung M 1993: The SOS chromotest - a review. Mutat Res 297: 235-279 
Randák T, Slavík O, Žlábek V, Horký P 2006: The Employment of Fish within the Frame of Monitoring the Contamination of Aquatic Environment by Allochthonous Substances. VÚV TGM Praha, 25 p. (in Czech)

Robson M, Spence K, Beech L 2006: Stream quality in a small urbanised catchment. Sci Total Environ 357: 194-207

Singh KP, Mohan D, Singh VK, Malik A 2005: Studies on distribution and fractionation of heavy metals in Gomti river sediments-a tributary of the Ganges, India. J Hydrol 312: 14-27

Sládeček V 1973: System of water quality from the biological point of view. Arch Hydrobiol Ergebn Limnol 7: 1-218

Svobodova Z, Celechovska O, Kolarova J, Randak T, Zlabek V 2004: Assessment of metal contamination in the upper reaches of the Ticha Orlice River. Czech J Anim Sci 49: 458-464

Vigano L, Camoirano A, Izzotti A, D’Agostini F, Polesello S, Francisci C, De Flora S 2002: Mutagenicity of sediments along the Po River and genotoxicity biomarkers in fish from polluted areas. Mutat Res 515: 125-134

Watanabe K, Sakamoto K, Sasaki T 1998a: Comparisons on chemically-induced mutation among four bacterial strains, Salmonella typhimurium TA102 and TA2638, and Escherichia coli WP/pKM101 and WP2 uvrA/ pKM101: collaborative study II. Mutat Res 412: 17-31

Watanabe K, Sasaki T, Kawakami K 1998b: Comparisons on chemically-induced mutation among four bacterial strains, Salmonella typhimurium TA102 and TA2638, and Escherichia coli WP/pKM101 and WP2 uvrA/ pKM101: collaborative study III and avaluation of the usefulness of these strains. Mutat Res 416: 169-181

Wilcox P, Naidoo A, Wedd DJ, Gatehouse DG 1990: Comparison of Salmonella typhimurium TA102 wit Escherichia coli WP2 tester strain. Mutagenesis 5: 285-291

White PA, Côté C 1998: Investigating the sources and fate of genotoxic substances in aquatic ecosystems with the SOS Chromotest. In: Wells, P.G., Lee, K., Blaise, C. (Eds.), Microscale Testing in Aquatic Toxicology \pm Advances, Techniques, and Practice. CRC Press, Boca Raton, pp. 607- 630

White PA, Rasmussen JB, Blaise C 1998: Genotoxic substances in the St. Lawrence system I: Industrial genotoxins sorbed to particulate matter in the St. Lawrence, St. Maurice, and Saguenay Rivers, Canada. Environ Toxicol Chem 17: 286-303

Wong PTS, Chau YK, Ali N, Whittle DM 1994: Biochemical and genotoxic effects in the vicinity of a pulp mill discharge. Environ Toxic Water Quality 9: 59-70

Xu H, Dutka BJ, Shurr K 1989: Microtitration SOS chromotest: A new approach in genotoxicity testing. Toxic Assess 4: 105-114 